\title{
Catherine Spencer, À corps perdus. Théâtre, désir, représentation
}

\section{Gabriella Bosco}

\section{(2) OpenEdition}

1 Journals

\section{Edizione digitale}

URL: https://journals.openedition.org/studifrancesi/46460

DOI: 10.4000/studifrancesi.46460

ISSN: 2421-5856

\section{Editore}

Rosenberg \& Sellier

\section{Edizione cartacea}

Data di pubblicazione: 1 octobre 2007

Paginazione: 492-493

ISSN: 0039-2944

\section{Notizia bibliografica digitale}

Gabriella Bosco, «Catherine Spencer, À corps perdus. Théâtre, désir, représentation», Studi Francesi

[Online], 152 (LI | II) | 2007, online dal 30 novembre 2015, consultato il 24 novembre 2021. URL: http:// journals.openedition.org/studifrancesi/46460 ; DOI: https://doi.org/10.4000/studifrancesi.46460

Questo documento è stato generato automaticamente il 24 novembre 2021.

\section{(c) (i) (9)}

Studi Francesi è distribuita con Licenza Creative Commons Attribuzione - Non commerciale - Non opere derivate 4.0 Internazionale. 


\title{
Catherine Spencer, À corps perdus. Théâtre, désir, représentation
}

\author{
Gabriella Bosco
}

\section{NOTIZIA}

CATHERINE SPENCER, À corps perdus. Théâtre, désir, représentation, L'Harmattan, 2005, pp.

226.

1 Partendo dall'Illusion comique di Corneille, citazione esemplare della messa in scena di una rappresentazione in cui Catherine SPENCER fa confluire i tre temi della scena come mise en abîme, della caverna platonica e di entrambe - scena teatrale e caverna - come simboli dell'utero femminile, À corps perdus si presenta come uno studio sul teatro in quanto luogo di manifestazione di un desiderio.

2 L'A., formatasi all'École Normale Supérieure di Parigi, da trent'anni vive e lavora negli Stati Uniti dove dirige il dipartimento di Lingua e Letteratura francese del Connecticut College (New London). La sua scrittura è frutto della confluenza degli studi semiologici svolti in Francia con i Cultural Studies versione americana.

3 Il punto di partenza del percorso condotto dall'A. in questo volume è nella condanna puritana e dei moralisti francesi del teatro perché immorale. È una prova a contrario cui l'A. ricorre, come espediente retorico, per dimostrare quanto sia connaturato al gesto rappresentativo il riferimento al desiderio, e dunque alla pulsione erotica. Ma il quesito cui il saggio intende rispondere è se esistano delle modalità proprie all'esperienza teatrale che possano essere analizzate come forme di attivazione del desiderio. I sondaggi sono in epoche e generi diversi: dalla Célimène di Rotrou a Nana di Zola, fino al Dernier métro di Truffaut e alla Legge del desiderio di Almodovar - il teatro dunque considerato anche nelle rappresentazioni che di esso sono date in altre forme espressive.

4 Lo strumento della dimostrazione che tenta l'A. è il corpo, nel suo travestimento scenico. Massimamente redditizio è quindi il caso del travestito come personaggio, il 
quale raddoppia - dal punto di vista della performance come da quello degli effetti sullo spettatore - la stimolazione del desiderio. 